\title{
Improved synthesis of SV2A targeting radiotracer $\left[{ }^{11} \mathrm{C}\right] \mathrm{UCB}-\mathrm{J}$
}

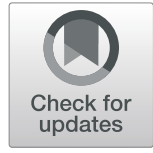

\author{
Johanna Rokka', Eva Schlein ${ }^{1}$ and Jonas Eriksson" ${ }^{2,3^{*}}$ (D)
}

\author{
* Correspondence: jonas.eriksson@ \\ ilk.uu.se \\ ${ }^{2}$ Department of Medicinal \\ Chemistry, Uppsala Biomedical \\ Center, Uppsala University, SE-751 \\ 23 Uppsala, Sweden \\ ${ }^{3}$ PET Centre, Uppsala University \\ Hospital, SE-751 85 Uppsala, \\ Sweden \\ Full list of author information is \\ available at the end of the article
}

\begin{abstract}
Introduction: $\left[{ }^{11} \mathrm{C}\right]$ UCB-J is a tracer developed for PET (positron emission tomography) that has high affinity towards synaptic vesicle glycoprotein 2A (SV2A), a protein believed to participate in the regulation of neurotransmitter release in neurons and endocrine cells. The localisation of SV2A in the synaptic terminals makes it a viable target for in vivo imaging of synaptic density in the brain. Several SV2A targeting compounds have been evaluated as PET tracers, including $\left[{ }^{11} \mathrm{C}\right] \mathrm{UCB}-J$, with the aim to facilitate studies of synaptic density in neurological diseases.

The original two-step synthesis method failed in our hands to produce sufficient amounts of $\left[{ }^{11} \mathrm{C}\right] \cup C B-J$, but served as an excellent starting point for further optimizations towards a high yielding and simplified one-step method. $\left[{ }^{11} \mathrm{C}\right]$ Methyl iodide was trapped in a clear THF-water solution containing the trifluoroborate substituted precursor, potassium carbonate and palladium complex. The resulting reaction mixture was heated at $70^{\circ} \mathrm{C}$ for 4 min to produce $\left[{ }^{11} \mathrm{C}\right] \cup C B-J$.
\end{abstract}

Results: After semi-preparative HPLC purification and reformulation in 10\% ethanol/ phosphate buffered saline, the product was obtained in $39 \pm 5 \%$ radiochemical yield based on $\left[{ }^{11} \mathrm{C}\right]$ methyl iodide, corresponding to $1.8 \pm 0.5 \mathrm{GBq}$ at EOS. The radiochemical purity was $>99 \%$ and the molar activity was $390 \pm 180 \mathrm{GBq} / \mu \mathrm{mol}$ at EOS. The product solution contained $<2$ ppb palladium.

Conclusions: A robust and high yielding production method has been developed for $\left[{ }^{11} \mathrm{C}\right]$ UCB-J, suitable for both preclinical and clinical PET applications.

Keywords: $\left[{ }^{11} \mathrm{C}\right]$ UCB-J, SVA2, Synaptic density, PET, Synaptic vesicle glycoprotein, Suzuki-Miyaura coupling, ${ }^{11} \mathrm{C}$-methylation

\section{Introduction}

The synaptic vesicle glycoprotein 2A (SV2A) is localized at synaptic vesicles in neurons and endocrine cells where it is believed to participate in the regulation of neurotransmitter release. The importance of SV2A for synaptic function is indicated for example by the antiepileptic action of levetiracetam (Lynch et al. 2004) which targets the protein, and by the development of seizures in knockout mice lacking SV2A (Janz et al. 1999). The localisation and apparent function of SV2A makes it a promising proxy marker for synaptic density that could be used to study neurodegenerative and psychiatric diseases in the brain (Finnema et al. 2016; Chen et al. 2018; Koole et al. 2019).

Several compounds with high affinity for SV2A, labelled with carbon-11 or fluorine18 , have been investigated as tracer candidates for in vivo quantification of SV2A with 
positron emission tomography (PET) (Heurling et al. 2019). One of the more promising candidates, $\left[{ }^{11} \mathrm{C}\right]$ UCB-J, was discovered by UCB Pharma (Braine-l'Alleud, Belgium) among 500+ compounds screened for binding affinity and was identified to have properties suitable for SV2A PET (Mercier et al. 2014). Preclinical evaluation at Yale PET centre revealed that $\left[{ }^{11} \mathrm{C}\right] \mathrm{UCB}-\mathrm{J}$ was indeed a promising ligand for SV2A imaging (Nabulsi et al. 2016) and recent publications have shown that $\left[{ }^{11} \mathrm{C}\right] \mathrm{UCB}-\mathrm{J}$ is a suitable PET tracer also for human studies (Finnema et al. 2016; Chen et al. 2018; Koole et al. 2019; Holmes et al. 2019). The original $\left[{ }^{11} \mathrm{C}\right]$ UCB-J synthesis was performed as a twostep reaction by ${ }^{11} \mathrm{C}$-methylation with $\left[{ }^{11} \mathrm{C}\right]$ methyl iodide under Suzuki-Miyaura coupling conditions (Nabulsi et al. 2016). $\left[{ }^{11} \mathrm{C}\right]$ Methyl iodide was reacted with a palladium (0) catalyst followed by addition and hydrolysis in situ of a trifluoroborate precursor to activate it towards palladium mediated ${ }^{11} \mathrm{C}$-methylation.

The Suzuki-Miyaura coupling can be described in three mechanistical steps; oxidative addition of an organohalide or triflate lacking beta-hydrogens to palladium (0), transmetalation of organoborane followed by a reductive elimination step where the product is formed. A suitable catalyst is the $\left[(\mathrm{o}-\mathrm{Tol})_{3} \mathrm{P}-\mathrm{Pd}-\mathrm{P}(\mathrm{o}-\mathrm{Tol})_{3}\right]$ complex, with a large cone angle $\left(194^{\circ}\right)$ appropriate for transmetalation (Schubiger et al. 2007). However, palladium mediated ${ }^{11} \mathrm{C}$-methylation differs from the general scheme of transition-metal-catalysis in the sense that the reaction is foremost optimized to consume the ${ }^{11} \mathrm{C}$-labelled precursor, in this case $\left[{ }^{11} \mathrm{C}\right]$ methyl iodide, while all other reagents and catalyst materials are employed in large excess, de facto ruling out a propagating catalytic cycle. The prerequisite of a short reaction time, necessitated by the rapid physical decay of carbon- $11\left(\mathrm{~T}_{1 / 2}=\right.$ $20.4 \mathrm{~min}$ ) is further helped by the very low quantities of $\left[{ }^{11} \mathrm{C}\right]$ methyl iodide used in the reaction (nano mole scale). A single clinical PET investigation in human typically requires a few hundred $\mathrm{MBq}$ of a ${ }^{11} \mathrm{C}$-tracer ready for injection and significantly more for multiple investigations. When we implemented the original $\left[{ }^{11} \mathrm{C}\right] \mathrm{UCB}-\mathrm{J}$ synthesis procedure, the method failed to give a sufficiently high radioactivity yield. After unsuccessful attempts to optimize the reaction in DMF-water we turned to another biphasic solvent mixture, THFwater, that efficiently facilitates hydrolysis of trifluoroborates while potentially supressing protodeboronation and other side reactions (Butters et al. 2010).

Here we describe our investigation towards a significantly improved synthesis of $\left[{ }^{11} \mathrm{C}\right] \mathrm{UCB}-J$ utilizing the same trifluoroborate substituted precursor that was described in the original synthesis, albeit obtained from a commercial vendor with high chemical purity. The result was a simplified and robust synthesis method performed in a single step which produced $\left[{ }^{11} \mathrm{C}\right] \mathrm{UCB}-\mathrm{J}$ in $39 \pm 5 \%$ radiochemical yield (RCY) based on $\left[{ }^{11} \mathrm{C}\right]$ methyl iodide.

\section{Methods}

Reaction mixtures were degassed with helium and vortexed before use. All reported radiochemical yields are decay corrected and based on $\left[{ }^{11} \mathrm{C}\right]$ methyl iodide.

\section{Materials}

The precursor for $\left[{ }^{11} \mathrm{C}\right] \mathrm{UCB}-\mathrm{J}$ synthesis, $(R)$-3-(difluoroboranyl)-4-((2-oxo-4-(3,4,5-trifluorophenyl) pyrrolidin-1-yl) methyl)-pyridin-1-ium fluoride $\left(\mathrm{BF}_{3}-\mathrm{Dm}-\mathrm{UCB}-\mathrm{J}\right)$ and the reference compound (4R)-1-[(3-methyl-4-pyridyl) methyl]-4-(3,4,5-trifluorophenyl) 
pyrrolidin-2-one (UCB-J), were purchased from Pharmasynth (Tartu, Estonia). Lithium aluminum hydride in THF $(0.1 \mathrm{M}, \mathrm{LAH})$ was purchased from ABX (Radeberg, Germany). Tris(dibenzylideneacetone)-dipalladium (0) $\left(\operatorname{Pd}_{2}(\mathrm{dba})_{3}\right)$, tri(o-tolyl)-phosphine $\left(\mathrm{P}(\mathrm{o}-\mathrm{tol})_{3}\right)$, anhydrous potassium carbonate, $\mathrm{N}, \mathrm{N}$-dimethylformamide (DMF), acetonitrile (ACN), 37\% ammonia solution, phosphorous pentoxide (Sicapent), Ascarite, hydriodic acid (57\%), trifluoroacetic acid (TFA) and tetrahydrofuran (THF) were purchased from Sigma Aldrich (Stockholm, Sweden). THF was distilled from a mixture containing sodium and benzophenone just before use to remove water and peroxides. Aqueous solution of TFA (1\%) was prepared by dilution with MilliQ water. Ethanol (99.5\%) was from Kemetyl (Haninge, Sweden). Phosphate buffer in saline (PBS, pH 7.4) and Kleptose $\odot$ (Hydroxypropyl betacyclodextrins $300 \mathrm{mg}$ in $9 \mathrm{mg} / \mathrm{mL} \mathrm{NaCl}$ solution) were from APL (Stockholm, Sweden). Ethanol-PBS solution (10\%) was prepared in house. Ammonium formate (AMF) buffer solution $(50 \mathrm{mM}, \mathrm{pH} 3.5)$ was purchased from Bio-Hospital (Kopparberg, Sweden). AMF buffer solution ( $\mathrm{pH} 10)$ was prepared by mixing ammonia solution $(40 \mathrm{~mL}, 37 \%)$ and AMF solution $(2000 \mathrm{~mL}, 50 \mathrm{mM}, \mathrm{pH}$ 3.5). The ${ }^{11} \mathrm{C}$-methylation reactions were performed in disposable conical glass vials (crimp neck, $0.9 \mathrm{~mL}$ ) with septa (11 $\mathrm{mm}$ aluminium crimp cap with $1.3 \mathrm{~mm}$ butyl/PTFE seal), purchased from VWR (Karlskoga, Sweden). Sep-Pak tC18 Plus Light Cartridges (WAT036805) were from Waters. Sterile filter $(0.22 \mu \mathrm{m}$ pore-size, Millex GV) was purchased from Millipore (Solna, Sweden).

\section{General methods}

\section{Synthesis equipment}

The synthesis, purification and reformulation procedures were fully automated using Tracer Production System (TPS) developed in-house (Uppsala University Hospital PET Centre, Sweden). The TPS device contains 10 modules, including a robotic liquid handler, a gripper with a shaker function, heating/cooling for reaction vials, injection port for semi-preparative HPLC, fraction collector, vortex evaporator, SPE reformulation system, sterile dispenser and a control software that allows independent tasks to run concurrently.

\section{Production of $\left[{ }^{11} \mathrm{C}\right]$ methyl iodide}

Carbon-11 obtained as $\left[{ }^{11} \mathrm{C}\right] \mathrm{CO}_{2}$ was produced through the ${ }^{14} \mathrm{~N}(\mathrm{p}, \alpha){ }^{11} \mathrm{C}$ nuclear reaction by $17 \mathrm{MeV}$ proton irradiation (Scanditronix MC-17 cyclotron) on nitrogen gas (AGA, Nitrogen 6.0) containing 0.05\% oxygen (AGA, Oxygen 4.6). Typical irradiation time was $30 \mathrm{~min}$, which gave approximately $30 \mathrm{GBq}\left[{ }^{11} \mathrm{C}_{\mathrm{CO}_{2}}\right.$ at the end of bombardment (EOB). The $\left[{ }^{11} \mathrm{C}\right] \mathrm{CO}_{2}$ was converted to $\left[{ }^{11} \mathrm{C}\right]$ methyl iodide by the "wet method". First, $\left[{ }^{11} \mathrm{C}\right] \mathrm{CO}_{2}$ was transferred to a reactor using helium gas $(100 \mathrm{~mL} / \mathrm{min})$ and trapped in $\mathrm{LAH}(300 \mu \mathrm{L}, 0.1 \mathrm{M})$. The mixture was evaporated to dryness at $80^{\circ} \mathrm{C}$ under a stream of nitrogen gas $(150 \mathrm{~mL} / \mathrm{min})$ during $2 \mathrm{~min}$. Hydroiodic acid $(600 \mu \mathrm{L}, 57 \%)$ was added to the reactor and mixture was heated at $130{ }^{\circ} \mathrm{C}$ for $70 \mathrm{~s}$ and then cooled to $80^{\circ} \mathrm{C}$. The formed $\left[{ }^{11} \mathrm{C}\right]$ methyl iodide was then transferred in a stream of nitrogen gas $(10 \mathrm{~mL} / \mathrm{min})$ to the reaction vessel via a phosphorous pentoxide/Ascarite column to remove moist and acidic vapors. Using this method, $18.3 \pm 3.6 \mathrm{GBq}\left[{ }^{11} \mathrm{C}\right]$ methyl iodide was produced $(n=20)$. 


\section{Product purification}

Purification of $\left[{ }^{11} \mathrm{C}\right] \mathrm{UCB}-\mathrm{J}$ was performed by semi preparative HPLC (Agilent 1260 Infinity II) using a Phenomenex Gemini $5 \mu \mathrm{m}$ NX-C18 $110 \AA(250 \times 10 \mathrm{~mm})$ column eluted with 40\% ACN in AMF buffer ( $\mathrm{pH} \mathrm{10)} \mathrm{at} 5 \mathrm{~mL} / \mathrm{min}$. The effluent was monitored with a Bioscan Flow-Count PMT radioactivity detector and UV detector (Agilent 1260 Infinity II) set at $254 \mathrm{~nm}$. The fraction containing $\left[{ }^{11} \mathrm{C}\right] \mathrm{UCB}-\mathrm{J}$ was collected at a retention time of approximately 10-11 $\mathrm{min}$.

\section{Radiochemical and chemical purity, identity and molar activity}

The radiochemical purity (RCP) and concentration of formulated $\left[{ }^{11} \mathrm{C}\right] \mathrm{UCB}-\mathrm{J}$ was assessed by analytical HPLC (VWR LaChrom Elite) equipped with an auto-sampler (L2200) and pump (L-2130). A Phenomenex Kinetex $5 \mu \mathrm{m} \mathrm{C18} 100 \AA$ A $(100 \times 3.0 \mathrm{~mm})$ column was eluted with $30 \% \mathrm{ACN}$ in $\mathrm{AMF}$ buffer $(\mathrm{pH} 3.5)$ at $0.7 \mathrm{~mL} / \mathrm{min}$. The effluent was monitored with a radioactivity detector (Bioscan Flow-Count PMT) and UV diode array detector set at $229-279 \mathrm{~nm}$. The identity of $\left[{ }^{11} \mathrm{C}\right] \mathrm{UCB}-\mathrm{J}$ was assessed by comparing the retention time of radioactive peak with the retention time of the UV peak for UCB-J, a non-radioactive reference compound added to the product sample. The molar activity was determined from the concentration of $\left[{ }^{11} \mathrm{C}\right] \mathrm{UCB}-\mathrm{J}$ and the radioactivity was measured in a dose calibrator and decay-corrected to end of synthesis (EOS). No chemical impurities were observed by UV-HPLC. The palladium concentration was analyzed in three batches of formulated product produced by the one-step synthesis. The palladium analyses were performed at the Department of Chemistry - BMC at Uppsala University using inductively coupled plasma atomic emission spectroscopy (ICP-AES).

\section{Synthesis of $\left[{ }^{11} \mathrm{C}\right]$ UCB-J}

\section{Original method, two-step synthesis in dmf-water (Method I)}

The original synthesis method for [ ${ }^{11}$ C]UCB-J (Nabulsi et al. 2016; Holmes et al. 2019) was implemented with minor modifications using the automated TPS synthesis system. $\mathrm{Pd}(\mathrm{dba})_{3}(0.4 \mathrm{mg}), \mathrm{P}(\mathrm{o}-\mathrm{tol})_{3}(0.4 \mathrm{mg})$ and potassium carbonate $(0.8 \mathrm{mg})$ were dissolved in DMF:water $(250 \mu \mathrm{L}, 8: 1 \mathrm{v} / \mathrm{v})$ forming an inhomogeneous dark red solution that gradually turned yellowish. After addition of $\left[{ }^{11} \mathrm{C}\right]$ methyl iodide in a stream of nitrogen gas, the resulting mixture was heated at $30^{\circ} \mathrm{C}$ for $3 \mathrm{~min}$ with brief and vigorous shakes at 1 and 2 min. The precursor (1.2 mg, $n=3$; or $3 \mathrm{mg}, n=2)$ in DMF:water $(100 \mu \mathrm{L}, 8: 1 \mathrm{v} / \mathrm{v})$ was then added and the resulting solution was heated at $100^{\circ} \mathrm{C}$ for $5 \mathrm{~min}$ while the vial was shaken briefly every $30 \mathrm{~s}$. The reaction vial was then cooled to $50{ }^{\circ} \mathrm{C}$ prior dilution of the reaction mixture with water $(600 \mu \mathrm{L})$. Purification of $\left[{ }^{11} \mathrm{C}\right] \mathrm{UCB}-\mathrm{J}$ was performed by semipreparative HPLC. The collected HPLC fraction containing $\left[{ }^{11} \mathrm{C}\right] \mathrm{UCB}-\mathrm{J}$ was mixed with Kleptose $\odot(0.3 \mathrm{~mL})$ and trifluoroacetic acid $(1 \mathrm{~mL})$. The resulting mixture was transferred to a vortex evaporator where it was evaporated to dryness within $5 \mathrm{~min}$, at a temperature of $20-55^{\circ} \mathrm{C}$. The product was then reformulated by addition of $10 \%$ ethanol in PBS (3 $\mathrm{mL}, \mathrm{pH} 7.4)$. The total synthesis time was $38 \pm 3 \mathrm{~min}(n=5)$.

\section{Two-step synthesis in THF-water (Method II)}

$\mathrm{Pd}_{2}(\mathrm{dba})_{3}(0.4 \mathrm{mg})$ and $\mathrm{P}(\mathrm{o}-\mathrm{tol})_{3}(0.5 \mathrm{mg})$ were dissolved in THF $(250 \mu \mathrm{L})$ forming a clear dark red solution that gradually turned yellowish. After addition of $\left[{ }^{11} \mathrm{C}\right]$ methyl 
iodide in a stream of nitrogen gas at room temperature the resulting solution was heated at $30^{\circ} \mathrm{C}$ for $3 \mathrm{~min}$ with brief and vigorous shakes at 1 and $2 \mathrm{~min}$. A solution of the precursor $\mathrm{BF}_{3}$-Dm-UCB-J $(1.1 \mathrm{mg})$ and $\mathrm{K}_{2} \mathrm{CO}_{3}(1.1 \mathrm{mg})$ in THF $(90 \mu \mathrm{L})$ and water $(40 \mu \mathrm{L})$ was then added to the reaction vial. The resulting reaction solution was heated at $70^{\circ} \mathrm{C}$ for $5 \mathrm{~min}$ and mixed by a vigorous shake of the vial at the start of the reaction and again after $1 \mathrm{~min}$. The $\left[{ }^{11} \mathrm{C}\right] \mathrm{UCB}-J$ was purified by semi-preparative HPLC and reformulated by vortex evaporation as described previously. The total synthesis time was $39 \pm 6 \min (n=7)$.

\section{One-step synthesis in THF-water (Method III)}

$\mathrm{Pd}_{2}(\mathrm{dba})_{3}(0.4 \mathrm{mg}), \mathrm{P}(\mathrm{o}-\mathrm{tol})_{3}(0.5 \mathrm{mg})$, potassium carbonate $(1.0 \mathrm{mg})$ and the precursor $\mathrm{BF}_{3}$-Dm-UCB-J $(1.1 \mathrm{mg})$ were dissolved in THF $(350 \mu \mathrm{L})$ and water $(40 \mu \mathrm{L})$ and the resulting homogenous dark red solution gradually turned yellowish. Approximately 15 min later, $\left[{ }^{11} \mathrm{C}\right]$ methyl iodide was added to the reaction mixture in a stream of nitrogen gas at room temperature. The resulting solution was heated at $70{ }^{\circ} \mathrm{C}$ for $4 \mathrm{~min}$ and mixed by a vigorous shake of the vial at the start of the reaction and again after $1 \mathrm{~min}$. The $\left[{ }^{11} \mathrm{C}\right] \mathrm{UCB}-J$ was purified by semi-preparative HPLC as described previously. The collected HPLC fraction was mixed with water $(20 \mathrm{~mL})$ and passed over a tC18 SepPak cartridge followed by rinsing of the cartridge with water $(2 \times 20 \mathrm{~mL})$. [ $\left.{ }^{11} \mathrm{C}\right] \mathrm{UCB}-\mathrm{J}$ was eluted with ethanol $(0.3 \mathrm{~mL})$ followed by PBS $(4.5 \mathrm{~mL})$ and sterile filtered into the sterile product vial. The total synthesis time was $39 \pm 3 \min (n=9)$.

\section{Results}

The original two-step $\left[{ }^{11} \mathrm{C}\right] \mathrm{UCB}-\mathrm{J}$ synthesis method gave in our hands less than $1 \%$ RCY based on $\left[{ }^{11} \mathrm{C}\right]$ methyl iodide, corresponding to $53 \pm 15 \mathrm{MBq}(n=3)$ at EOS, Table 1. Performing the same reaction in THF-water increased the RCY significantly to $16 \pm 5 \%(n=7)$. In these tests the end-product was formulated using vortex evaporation, where the recovery of the product from the formulation process was only $50 \%$. When performing the synthesis in one-step and formulating the product by solid phase extraction (90\% recovery) the RCY was $39 \pm 5 \%$, corresponding to $1.8 \pm 0.5 \mathrm{GBq}$ at EOS (Scheme 1, Table 1). The molar activity was $390 \pm 180 \mathrm{GBq} / \mu \mathrm{mol}$ at EOS and the

Table 1 Optimization of the $\left[{ }^{11} \mathrm{C}\right] \cup C B-J$ synthesis

\begin{tabular}{|c|c|c|c|c|c|c|c|c|c|}
\hline Method & $\begin{array}{l}\text { Reaction } \\
\text { steps }\end{array}$ & $\begin{array}{l}{\left[{ }^{11} \mathrm{C}\right]} \\
\mathrm{CH}_{3} \mathrm{l}[\mathrm{GBq}]^{\mathrm{C}}\end{array}$ & $\begin{array}{l}\text { Precursor } \\
{[\mathrm{mg}]}\end{array}$ & Solvent & $\begin{array}{l}\text { Reaction } \\
\text { temperature }\end{array}$ & $\begin{array}{l}\text { Reaction } \\
\text { Time (min) }\end{array}$ & $\begin{array}{l}\left.{ }^{11} \mathrm{C}\right] \cup C B-J \\
{[\mathrm{MBq}]^{\mathrm{d}}}\end{array}$ & $R C Y^{e}$ & $\overline{n^{f}}$ \\
\hline 1 & $2^{a}$ & $18 \pm 4$ & $1.2 \pm 0.1$ & $\begin{array}{l}\text { DMF- } \mathrm{H}_{2} \mathrm{O} \\
(8: 1)\end{array}$ & $30^{\circ} \mathrm{C}+100^{\circ} \mathrm{C}$ & $3+5$ & $53 \pm 15$ & $<1 \%$ & 3 \\
\hline I & $2^{a}$ & $18 ; 20$ & $3.0 ; 3.0$ & $\begin{array}{l}\text { DMF- } \mathrm{H}_{2} \mathrm{O} \\
(8: 1)\end{array}$ & $30{ }^{\circ} \mathrm{C}+100{ }^{\circ} \mathrm{C}$ & $3+5$ & $138 ; 216$ & $\begin{array}{l}3 \% \\
4 \%\end{array}$ & 2 \\
\hline$\|$ & $2^{a}$ & $21 \pm 4$ & $1.1 \pm 0.1$ & $\begin{array}{l}\mathrm{THF}-\mathrm{H}_{2} \mathrm{O} \\
(34: 4)\end{array}$ & $30^{\circ} \mathrm{C}+70^{\circ} \mathrm{C}$ & $3+5$ & $890 \pm 240$ & $\begin{array}{l}16 \pm \\
5 \%\end{array}$ & 7 \\
\hline III & $1^{\mathrm{b}}$ & $17 \pm 2$ & $1.1 \pm 0.1$ & $\begin{array}{l}\mathrm{THF}-\mathrm{H}_{2} \mathrm{O} \\
(35: 4)\end{array}$ & $70^{\circ} \mathrm{C}$ & 4 & $1780 \pm 460$ & $\begin{array}{l}39 \pm \\
5 \%\end{array}$ & 9 \\
\hline
\end{tabular}

${ }^{\mathrm{a}}$ Formulated by vortex evaporator method

${ }^{b}$ Formulated by Sep-Pak method

'Starting activity

${ }^{\mathrm{d}}$ At EOS

${ }^{e} \mathrm{RCY}$ based on $\left[{ }^{11} \mathrm{C}\right] \mathrm{CH}_{3} \mathrm{l}$

${ }^{f}$ Number of experiments 
radiochemical purity was $>99 \%$ at $1 \mathrm{~h}$ after EOS. The palladium concentration in the product solution was $1.7 \pm 0.5 \mathrm{ng} / \mathrm{mL}(n=3)$.

\section{Discussion}

The original synthesis procedure (Nabulsi et al. 2016) failed in our hands to produce sufficient amounts of $\left[{ }^{11} \mathrm{C}\right] \mathrm{UCB}-J$, but served as an excellent starting point for optimizing the reaction conditions. The reaction was performed in two steps where $\left[{ }^{11} \mathrm{C}\right] \mathrm{me}$ thyl iodide was reacted with a palladium complex formed in a mixture of $\left.\operatorname{Pd}_{2}(\mathrm{dba})_{3}\right)$, $\mathrm{P}(\mathrm{o}-\mathrm{tol})_{3}$ and potassium carbonate in DMF-water at ambient temperature. The trifluoroborate substituted precursor was then added and the resulting mixture was heated to produce $\left[{ }^{11} \mathrm{C}\right] \mathrm{UCB}-J$. When modifying the reaction conditions, it was found that a prolonged reaction time did not improve the RCY, nor did an increase of the precursor load from $1 \mathrm{mg}$ to $3 \mathrm{mg}$ or changes in the reaction temperature.

The inhomogeneous character of the prepared reaction mixtures in DMF-water were visually apparent. DMF or DMF-water solutions are commonly used in coupling reactions with $\left[{ }^{11} \mathrm{C}\right]$ methyl iodide and borate precursors in the presence of palladium catalysts (Nabulsi et al. 2016; Holmes et al. 2019; Hamill et al. 2005; Takahashi et al. 2014; Wilson et al. 2018). However, palladium complexes are usually only slightly soluble in DMF-water mixtures and solid particles are easily formed which may result in the precipitation of $\left[{ }^{11} \mathrm{C}\right]$ methylated palladium complexes potentially making them less accessible for reaction.

Mechanistical studies show that trifluoroboronate substrates need to undergo hydrolysis to boronic acid derivatives, $\left.\left[\mathrm{RBF}_{3-\mathrm{n}}\right)(\mathrm{OH})_{\mathrm{n}}\right]^{-}$, in order to act as transmetalating species (Butters et al. 2010). As the hydrolysis may occur more efficiently in the minor aqueous phase which is much more basic than the major organic phase, the formation of boronic acid derivatives may also depend on efficient agitation. However, continuous agitation or prefiltration did not improve the RCY of $\left[{ }^{11} \mathrm{C}\right] \mathrm{UCB}-\mathrm{J}$ in our tests with DMF-water solvent mixtures.

The original synthesis method used a precursor batch which contained approximately $3 \%$ of the boronic acid derivative. (Nabulsi et al. 2016; Holmes et al. 2019) Recently another research group published a $\left[{ }^{11} \mathrm{C}\right] \mathrm{UCB}-\mathrm{J}$ synthesis method where the precursor batch deliberately contained 5\% boronic acid derivative (Bertoglio et al. 2019). In addition, a brief note on the synthesis of $\left[{ }^{11} \mathrm{C}\right] \mathrm{UCB}-\mathrm{J}$ via in situ generation of the boronic acid derivative was published as an abstract for EANM 2017 (Onega et al. 2017).

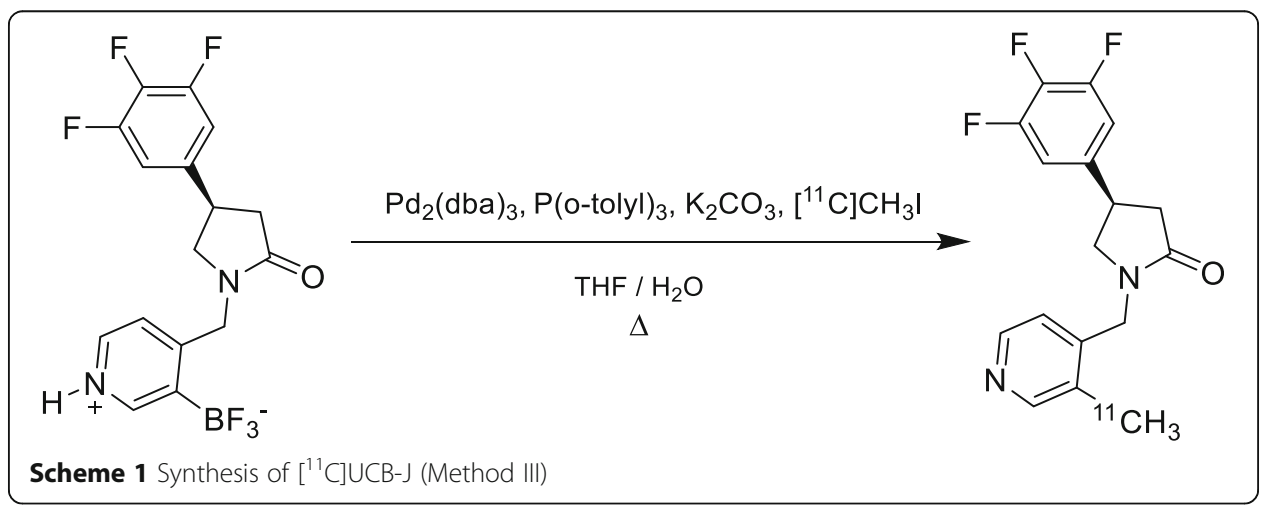


These reports gave further evidence that boronic acids play an important role in the $\left[{ }^{11} \mathrm{C}\right] \mathrm{UCB}-\mathrm{J}$ synthesis and help to explain why the original synthesis procedure does not perform satisfactorily when applied with high purity batches of the organotrifluoroborate precursor. The UCB-J precursor batch we used was purchased from a commercial manufacturer and had high chemical purity (98.9\%). For this reason, we tested to treat the precursor with aqueous carbonate solution to promote hydrolysis before the ${ }^{11} \mathrm{C}$ methylation reaction. However, premixing the precursor with carbonate approximately $30 \mathrm{~min}$ before the reaction did not significantly improve the radiochemical yield ( $3 \%$ and $4 \%, n=2$ ).

Unlike boronic acids, organotrifluoroborates are stable in crystalline solid form and in aprotic solutions making them attractive as precursor materials for synthesis of PETtracers (Lennox and Lloyd-Jones 2014). However, as already mentioned trifluoroborates need to be converted to boronic acid derivatives in aqueous or protic media to be activated for transmetalation reactions (Lennox and Lloyd-Jones 2014). While conventional catalysis reactions with organotrifluoroborates can proceed for hours, the short half-life of carbon-11 necessitate very short reaction time of a few minutes and rapid initial formation of boronic acid is therefore needed. Boronic acid derivatives have also been used directly as precursors in Suzuki-Miyaura reactions, for example in the synthesis of $\left[{ }^{11} \mathrm{C}\right] \mathrm{M}-\mathrm{MTEB}$ (Hamill et al. 2005). However, boronic acids can undergo side reactions under coupling conditions, e.g. oxidation, protodeboronation and palladium catalyzed homocoupling. By hydrolyzing trifluoroborates in situ to form moderate concentrations of active species, the reaction can be directed towards the Suzuki-Miyaura coupling reaction more selectively (Lennox and Lloyd-Jones 2014). The hydrolysis rate of trifluoroborates can be controlled in biphasic solvent system that has slightly basic organic phase and very basic aqueous phase. (Lennox and Lloyd-Jones 2014) Besides DMFwater solvent systems, hydrolysis can also occur in more homogenous solvent mixtures such as THF and water in a 10:1 ratio in the presence of a carbonate salt (Lennox and Lloyd-Jones 2014). THF has also shown to be an excellent solvent for other types of transition metal mediated ${ }^{11} \mathrm{C}$-labelling reactions, e.g. carbonylations (Eriksson et al. 2012; Takashima-Hirano et al. 2012; Roslin et al. 2017; Schembri et al. 2019) and Heck reactions (Wang et al. 2015).

When DMF-water was replaced by THF-water in the two step synthesis of $\left[{ }^{11} \mathrm{C}\right] \mathrm{UCB}-\mathrm{J}$, the RCY based on $\left[{ }^{11} \mathrm{C}\right]$ methyl iodide was increased from less than $1 \%$ to $16 \pm 5 \%(n=7)$. The optimal reaction temperature was $70^{\circ} \mathrm{C}$, near the boiling point of the solvent and $30^{\circ} \mathrm{C}$ lower than the original method (Nabulsi et al. 2016; Holmes et al. 2019). Heating the vial at temperatures over $70^{\circ} \mathrm{C}$ did not improve the radiochemical yield but caused higher pressure in the reaction vessel and an increased risk for the vial septum to leak. The effect of the solvent change was visually apparent as THF-water gave clear solutions while DMF-water gave inhomogeneous mixtures containing particulates. Hence, the concentration of the active reagent species in solution may have been enhanced by the higher solubility in THF-water. It could also be speculated that THFwater solvent promoted more rapid initial formation of boronic acid derivatives from the precursor, as well as an improved solvation of the active catalyst complex. Given the lack of preceding studies, further investigations will be needed to confirm the general utility of THF-water as a preferred solvent system for ${ }^{11} \mathrm{C}$-labelling by the SuzukiMiyaura coupling reaction. 
Finally, when the synthesis of $\left[{ }^{11} \mathrm{C}\right] \mathrm{UCB}-\mathrm{J}$ was performed in a single step, mixing all reagents before adding the $\left[{ }^{11} \mathrm{C}\right]$ methyl iodide, the procedure was greatly simplified and the RCY based on $\left[{ }^{11} \mathrm{C}\right]$ methyl iodide was further improved to $39 \pm 5 \%(n=9)$, corresponding to $1.8 \pm 0.5 \mathrm{GBq}$ at EOS (Table 1 ). Quality control showed that $\left[{ }^{11} \mathrm{C}\right] \mathrm{UCB}-\mathrm{J}$ was produced with high radiochemical yield, radiochemical purity and molar activity. The amount of $\left[{ }^{11} \mathrm{C}\right]$ methyl iodide used in the reactions were approximately $20 \mathrm{GBq}$, with larger starting activity the radioactivity yield of $\left[{ }^{11} \mathrm{C}\right] \mathrm{UCB}-\mathrm{J}$ could be improved further.

In our investigations, freshly distilled THF over sodium was used because our laboratory has a distillation unit for everyday use. However, when testing the reaction with THF straight from the bottle the RCY remained the same. Thus, it was concluded that freshly distilled THF was not really needed.

In the publications describing the original synthesis of $\left[{ }^{11} \mathrm{C}\right] \mathrm{UCB}-J$, the $\left[{ }^{11} \mathrm{C}\right]$ methyl iodide was trapped in the reaction vessel cooled by an acetone/ice bath (Nabulsi et al. 2016; Holmes et al. 2019). To investigate if cooling was necessary when performing the reaction in THF-water, tests were made showing that more than $80 \%$ of $\left[{ }^{11} \mathrm{C}\right]$ methyl iodide was recovered in the reaction vessel at room temperature, hence it was concluded that $\left[{ }^{11} \mathrm{C}\right]$ methyl iodide was trapped efficiently in THF-water without cooling. Another simplification compared to the original method was to omit acidification and filtration and instead rely on separation of palladium species by semi-preparative HPLC. Analysis performed by ICP-AES confirmed that the residual concentration of palladium in the formulated product was insignificant (approx. $2 \mathrm{ppb}$ ).

Solid-phase extraction using tC18 light cartridge was preferred over vortex evaporation for the reformulation process using the high yielding one-step synthesis due to excellent product recovery from the formulation process, $90 \%$, based on the activity in the collected HPLC fraction. $\left[{ }^{11} \mathrm{C}\right] \mathrm{UCB}-\mathrm{J}$ was released from the cartridge using $300 \mu \mathrm{L}$ ethanol followed by $3 \mathrm{~mL}$ PBS solution. High activity concentration was important in an on-going PET study in mice where maximum injection volume was $100 \mu \mathrm{L}$ and the product solution could contain no more than $10 \%$ ethanol.

\section{Conclusions}

$\left[{ }^{11} \mathrm{C}\right]$ UCB-J was synthesized in $39 \pm 5 \% \mathrm{RCY}$ based on $\left[{ }^{11} \mathrm{C}\right]$ methyl iodide, corresponding to $1.8 \pm 0.5 \mathrm{GBq}$ at $\mathrm{EOS}$ in a one-step reaction from $\left[{ }^{11} \mathrm{C}\right]$ methyl iodide. Besides producing $\left[{ }^{11} \mathrm{C}\right] \mathrm{UCB}-\mathrm{J}$ in sufficient amounts for clinical PET studies this improved synthesis method present practical simplifications compared to the original method. The ${ }^{11} \mathrm{C}$-methylation reaction was performed in a single step with commercially available precursor at reduced temperature and shortened reaction time. THF-water produced a more homogenous reaction mixture and no filtration was needed prior semipreparative HPLC. The method has proven robust and several batches of $\left[{ }^{11} \mathrm{C}\right] \mathrm{UCB}-\mathrm{J}$ has been used in preclinical imaging studies. 


\section{Funding}

This project has received funding from the European Union's Horizon 2020 research and innovation programme under the Marie Skłodowska-Curie grant agreement No 813528. Funding was also received from BioArctic AB.

\section{Availability of data and materials}

The authors declare that data supporting the findings of this study are available within the article or are available from the corresponding author on reasonable request.

\section{Ethics approval and consent to participate}

Not applicable.

\section{Consent for publication}

Not applicable.

\section{Competing interests}

The authors declare that they have no competing interests.

\section{Author details}

1Department of Public Health and Caring Sciences/Geriatrics, Uppsala University, Rudbeck Laboratory, 75185 Uppsala, Sweden. ${ }^{2}$ Department of Medicinal Chemistry, Uppsala Biomedical Center, Uppsala University, SE-751 23 Uppsala, Sweden. ${ }^{3}$ PET Centre, Uppsala University Hospital, SE-751 85 Uppsala, Sweden.

\section{Received: 9 September 2019 Accepted: 18 October 2019}

Published online: 29 November 2019

\section{References}

Bertoglio, D.; Verhaeghe, J.; Miranda, A.; Kertesz, l.; Cybulska, K.; Korat, Š.; Wyffels, L.; Stroobants, S.; Mrzljak, L; Dominguez, C.; et al. Validation and Noninvasive Kinetic Modeling of $\left[{ }^{11}\right.$ C]UCB-J PET Imaging in Mice. J Cereb Blood Flow Metab. 2019, 0271678X1986408. doi: https://doi.org/10.1177/0271678X19864081.

Butters M, Harvey JN, Jover J, Lennox AJJ, Lloyd-Jones GC, Murray PM. Aryl Trifluoroborates in Suzuki-Miyaura coupling: the roles of endogenous aryl Boronic acid and fluoride. Angew Chem Int Ed. 2010;49(30):5156-60. https://doi.org/10.1002/ anie.201001522.

Chen M-KK, Mecca AP, Naganawa M, Finnema SJ, Toyonaga T, Lin SF, Najafzadeh S, Ropchan J, Lu Y, McDonald JW, et al. Assessing synaptic density in Alzheimer disease with synaptic vesicle glycoprotein 2A positron emission tomographic imaging. JAMA Neurol. 2018;75(10):1215-24. https://doi.org/10.1001/jamaneurol.2018.1836.

Eriksson J, Van Den Hoek J, Windhorst AD. Transition metal mediated synthesis using [ $11 \mathrm{C}] \mathrm{CO}$ at low pressure - a simplified method for 11C-Carbonylation. J Label Compd Radiopharm. 2012;55(6):223-8. https://doi.org/10.1002/jlcr.2930,

Finnema SJ, Nabulsi NB, Eid T, Detyniecki K, Lin S, Chen M-K, Dhaher R, Matuskey D, Baum E, Holden D, et al. Imaging Synaptic Density in the Living Human Brain. Sci Transl Med. 2016;8(348):348ra96. https://doi.org/10.1126/scitransImed. aaf6667.

Hamill TG, Krause S, Ryan C, Bonnefous C, Govek S, Seiders TJ, Cosford NDP, Roppe J, Kamenecka T, Patel S, et al. Synthesis, characterization, and first successful monkey imaging studies of metabotropic glutamate receptor subtype 5 (MGluR5) PET radiotracers. Synapse. 2005;56(4):205-16. https://doi.org/10.1002/syn.20147.

Heurling K, Ashton NJ, Leuzy A, Zimmer ER, Blennow K, Zetterberg H, Eriksson J, Lubberink M, Schöll M. Synaptic Vesicle Protein 2A as a Potential Biomarker in Synaptopathies. Mol Cell Neurosci. 2019:1-9. https://doi.org/10.1016/j.mcn.2019.02. 001.

Holmes SE, Scheinost D, Finnema SJ, Naganawa M, Davis MT, DellaGioia N, Nabulsi N, Matuskey D, Angarita GA, Pietrzak RH, et al. Lower synaptic density is associated with depression severity and network alterations. Nat Commun. 2019;10(1):110. https://doi.org/10.1038/s41467-019-09562-7.

Janz R, Goda Y, Geppert M, Missler M, Südhof TC. SV2A and SV2B function as redundant Ca2+ regulators in neurotransmitter release. Neuron. 1999;24(4):1003-16. https://doi.org/10.1016/50896-6273(00)81046-6.

Koole M, van Aalst J, Devrome M, Mertens N, Serdons K, Lacroix B, Mercier J, Sciberras D, Maguire P, Van Laere K. Quantifying SV2A density and drug occupancy in the human brain using [11C]UCB-J PET imaging and subcortical white matter as reference tissue. Eur J Nucl Med Mol Imaging. 2019;46(2):396-406. https://doi.org/10.1007/s00259-018-4119-8.

Lennox AJJ, Lloyd-Jones GC. Selection of boron reagents for Suzuki-Miyaura coupling. Chem Soc Rev. 2014;43(1):412-43. https://doi.org/10.1039/C3CS60197H.

Lynch BA, Lambeng N, Nocka K, Kensel-Hammes P, Bajjalieh SM, Matagne A, Fuks B. The synaptic vesicle protein SV2A is the binding site for the antiepileptic drug Levetiracetam. Proc Natl Acad Sci U S A. 2004;101(26):9861-6. https://doi.org/10. 1073/PNAS.0308208101.

Mercier J, Archen L, Bollu V, Carré S, Evrard Y, Jnoff E, Kenda B, Lallemand B, Michel P, Montel F, et al. Discovery of heterocyclic Nonacetamide synaptic vesicle Protein 2A (SV2A) ligands with single-digit Nanomolar potency: opening avenues towards the first SV2A positron emission tomography (PET) ligands. ChemMedChem. 2014;9(4):693-8. https:// doi.org/10.1002/cmdc.201300482.

Nabulsi NB, Mercier J, Holden D, Carre S, Najafzadeh S, Vandergeten M-C, Lin S f, Deo A, Price N, Wood M, et al. Synthesis and Preclinical Evaluation of 11C-UCB-J as a PET Tracer for Imaging the Synaptic Vesicle Glycoprotein 2A in the Brain. J Nucl Med. 2016;57(5):777-84. https://doi.org/10.2967/jnumed.115.168179.

Onega M, Chong H, Roble A, Plisson C, Huiban M, Mercier J, Vandergeten M, Passchier J. Highly improved and GMP compliant synthesis of [11C]UCB-J: in situ generation of Boronic acid precursor. Eur J Nucl Med Mol Imaging. 2017; 44(Suppl 2):S528.

Roslin S, Brandt P, Nordeman P, Larhed M, Odell LR, Erikssoni J. Synthesis of 11 C-Labelled Ureas by palladium (II)-mediated oxidative Carbonylation. Molecules. 2017;22(10):1688. https://doi.org/10.3390/molecules22101688. 
Schembri LS, Eriksson J, Odell LR. Palladium (0)-catalyzed Carbonylative synthesis of N -Acylsulfonamides via Regioselective acylation. J Organomet Chem. 2019;84(11):6970-81. https://doi.org/10.1021/acs.joc.9b00740.

Schubiger PA, Lehmann L, Friebe M. PET Chemistry: The Driving Force in Molecular Imaging. Berlin: Springer; 2007. pp 191195

Takahashi K, Hosoya T, Onoe K, Doi H, Nagata H, Hiramatsu T, Li X-L, Watanabe Y, Wada Y, Takashima T, et al. 11C-Cetrozole: an improved C-11C-methylated PET probe for aromatase imaging in the brain. J Nucl Med. 2014;55(5):852-7. https://doi. org/10.2967/jnumed.113.131474.

Takashima-Hirano M, Ishii H, Suzuki M. Synthesis of [11C] Am80 via novel Pd(0)-mediated [11C] Carbonylation using Arylboronate and [11C] carbon monoxide. ACS Med Chem Lett. 2012;3(10):804. https://doi.org/10.1021/ML300160W.

Wang H, Liu L, Lu Y, Pan P, Hooker JM, Fowler JS, Tonge PJ. Radiolabelling and positron emission tomography of PT70, a time-dependent inhibitor of InhA, the mycobacterium tuberculosis Enoyl-ACP Reductase. Bioorg Med Chem Lett. 2015; 25(21):4782-6. https://doi.org/10.1016/j.bmcl.2015.07.019.

Wilson TC, Cailly T, Gouverneur V. Boron reagents for divergent radiochemistry. Chem Soc Rev. 2018;47(18):6990-7005. https://doi.org/10.1039/C8CS00499D.

\section{Publisher's Note}

Springer Nature remains neutral with regard to jurisdictional claims in published maps and institutional affiliations.

Submit your manuscript to a SpringerOpen ${ }^{\circ}$ journal and benefit from:

- Convenient online submission

- Rigorous peer review

- Open access: articles freely available online

High visibility within the field

Retaining the copyright to your article

Submit your next manuscript at $\boldsymbol{s p r i n g e r o p e n . c o m ~}$ 